ORIGINAL ARTICLE

\title{
Effects of exercise on the physical condition of college rugby players during summer training camp
}

\author{
T Mashiko, T Umeda, S Nakaji, K Sugawara
}

Br J Sports Med 2004;38:186-190. doi: 10.1136/bjsm.2002.004333

See end of article for authors' affiliations

Correspondence to: S Nakaji, Department of Hygiene, Hirosaki University School of Medicine, Zaifu-cho 5 , Hirosaki City, 036-8562 Aomori, Japan; tume@ cc.hirosaki-u.ac.jp

Accepted 15 April 2003

\begin{abstract}
Objectives: To determine the effects of exercise training on physical condition in 25 college rugby players during a summer training camp, and to compare these variables by the different players' positions.

Methods: Changes in body composition parameters and blood biochemistry were examined before and after a summer training camp.

Results: Body weight and percentage body fat did not change significantly during the camp. There were significant decreases in levels of serum total cholesterol, triglycerides, phosphate, uric acid, and immunoglobulin $G$ and $M$. In contrast, there were significant increases in levels of serum potassium, markers of renal, hepatic, and muscular damage (BUN, GOT, GPT, LDH, CK), and complement C4. Comparison of the changes in biochemical parameters between rugby players playing in different positions showed a significant increase in serum albumin level in the forwards, and significant decreases in serum triglyceride and sodium levels in the backs. The magnitude of change in serum LDH during the camp was significantly greater $(p<0.05)$ for the forwards than for the backs.

Conclusions: These data suggest that, in rugby players attending a 20 day camp, exercise training resulted in muscular damage, loss of electrolytes due to sweating, and changes in immune function. Backs exhibited a higher rate of fat metabolism and loss of electrolytes than forwards, possibly because they did more running during the camp. In contrast, forwards experienced more physical contact, performed more physically strenuous exercise, and exhibited higher levels of muscular damage and tissue protein degradation.
\end{abstract}

B ecause rugby in Japan is played in autumn and winter, many teams use summer training camps to improve their players' physical fitness and skill levels. To prevent injury and heat stroke during summer games and training, the Japanese Rugby Association advises its members to take preventive measures such as regular medical examinations. ${ }^{1}$ Although teams tend to follow this advice, injuries often occur during summer training camps in Japan, ${ }^{2}{ }^{3}$ due both to strenuous exercise and the hot summer conditions.

This study had two objectives: firstly, to assess the effects of a summer training camp on the physical condition, and to analyse selected body composition parameters and blood biochemical variables in college rugby players; secondly, to determine whether responses in these variables differed between athletes according to player position. Understanding these responses in rugby players is an important first step towards identifying potential problems that may arise from intense training during these summer camps, and give clues as to how to deal with them in position-specific post-camp training and rest regimens.

\section{METHODS}

\section{Subjects and study period}

The subjects in this study were 25 members of a college rugby team belonging to the East Japan Universities League. The players' mean height was $175.4 \mathrm{~cm}$, body weight $81.8 \mathrm{~kg}$, percentage body fat $16.3 \%$, and age 20.2 years old. The subjects consisted of 13 back (backs) and 12 forward (forwards) players (table 1).

The present study was conducted on 2 days: August 13, 1997 (immediately before the start of the camp), and August 30, 1997 (immediately before completion of the camp). Before the camp, players were training for approximately $2 \mathrm{~h}$ /day and 6 days/week; during the camp, they trained for $6 \mathrm{~h}$ /day
( $3 \mathrm{~h}$ in the morning and $3 \mathrm{~h}$ in the afternoon) for all days of the camp. The mean value of the dry bulb temperature in the daytime was $23.9 \pm 2.5^{\circ} \mathrm{C}$ during the camp.

Approval for this study was obtained from the Ethics Committee of Hirosaki University School of Medicine. Before the study began, the study protocol and purpose were explained to the subjects and informed consent was obtained from each of them.

\section{Anthropometry and blood biochemistry}

Physical measurements were performed before breakfast and all subjects wore training gear. Body weight was measured using a digital scale (UC-300, A \& D, Tokyo), and percentage body fat was measured using a near-infrared body fat analyser (BFT-300, Ket Science Laboratory, Tokyo).

Venous blood samples $(10 \mathrm{ml})$ were collected from the forearm vein after overnight fasting. Samples were centrifuged to separate serum at $3000 \mathrm{~g}$ for $15 \mathrm{~min}$, and serum samples were stored at $-80^{\circ} \mathrm{C}$ until blood biochemistry analysis. Biochemical analyses were performed on whole blood to assess markers of dehydration and haemoconcentration [levels of haemoglobin ( $\mathrm{Hb})$ and haematocrit (Hct)], and inflammation and heat stroke [white blood cell count (WBC)]. Serum samples were used to determine: energy metabolism and nutritional intake [levels of total protein (TP), albumin (Alb), total cholesterol (TC), HDL cholesterol (HDL-C), triglyceride (TG), iron (Fe), calcium (Ca), phosphate $(\mathrm{Pi})$, sodium $(\mathrm{Na})$, potassium $(\mathrm{K})$ and chloride $(\mathrm{Cl})]$, renal function [levels of uric nitrogen (BUN), creatinine $(\mathrm{Cr})$ and uric acid (UA)], muscular activity, muscular injury, and hepatic function [levels of glutamate oxaloacetic transaminase (GOT), glutamate pyruvic transaminase (GPT), lactate dehydrogenase $(\mathrm{LDH})$ and creatine kinase $(\mathrm{CK})]$, and immune function [levels of immunoglobulins (IgG, IgA, and IgM) and complements (C3 and C4)]. 
Table 1 Changes in levels of body composition parameters during the summer camp training

\begin{tabular}{|c|c|c|c|c|c|c|}
\hline \multirow[b]{2}{*}{ Variable } & \multicolumn{2}{|c|}{ All players $(n=25)$} & \multicolumn{2}{|c|}{ Forward players $(n=12)$} & \multicolumn{2}{|c|}{ Back players $(n=13)$} \\
\hline & Before & After & Before & After & Before & After \\
\hline Height $(\mathrm{cm})$ & $175.4 \pm 7.3$ & - & $178.9 \pm 5.5$ & - & $172.0 \pm 7.5$ & - \\
\hline Weight (kg) & $81.8 \pm 10.9$ & $80.6 \pm 10.7$ & $88.0 \pm 8.6$ & $87.9 \pm 8.7$ & $75.5 \pm 9.6$ & $75.4 \pm 8.9$ \\
\hline$\%$ Fat $(\%)$ & $16.3 \pm 3.3$ & $15.0 \pm 3.7$ & $17.2 \pm 3.7$ & $16.0 \pm 5.1$ & $14.8 \pm 2.5$ & $14.2 \pm 2.2$ \\
\hline
\end{tabular}

WBC, Hct, and $\mathrm{Hb}$ were measured using an automatic cytometer (Micro Biff-II, Coulter, CA, USA). TP was measured using the Biuret method; Alb using the Bromcresol Green method; TC, TG, and Glu using the enzyme method; HDL-C using the dextran-magnesium chloride method; apoproteins using the turbidimetric immunoassay (TIA) method; GOT, GPT, LDH, and CK using the ultraviolet (UV) method; UA using the uricase-enzyme method; BUN using the Urease-UV method; Cr using the Jaffe method; immunoglobulins and complements using the TIA method; Fe using the Ferrosime method; Ca using the $o$-cresol phthalein complexone method; Pi using the enzyme method; Na using the glass electrode method; $\mathrm{K}$ using the valinomycin method; and $\mathrm{Cl}$ using the silver chloride electrode method.

\section{Statistics}

Data were expressed as mean values \pm standard deviation (SD). Changes in parameters between the start and end of the camp were compared using a paired $t$ test. Differences in parameters between the forwards and backs were analysed using a generalised Wilcoxon test. p values of less than 0.05 were considered significant.

\section{RESULTS}

Table 1 shows the changes in body composition parameters during the camp. Body weight and \% body fat were not changed significantly after the camp.

Table 2 shows the changes in serum protein and lipids during the camp. In all players, TC and TG levels decreased significantly after the camp (each $\mathrm{p}<0.01)$. In both the forwards and backs, TC level decreased significantly $(\mathrm{p}<0.05$, $\mathrm{p}<0.01$, respectively). In the backs only, Alb level increased and TG level decreased after the camp $(\mathrm{p}<0.05$ for each variable).

Table 3 shows the levels of BUN, Cr, and UA before and after the camp. In all players, BUN increased significantly after the camp $(p<0.01)$, whereas UA decreased $(p<0.01)$. Although BUN significantly increased in both forwards and backs $(p<0.01$ and $p<0.05$, respectively), UA declined significantly only in the forwards $(\mathrm{p}<0.01)$.

Table 4 shows data on serum levels of GOT, GPT, LDH, and CK. In all players and in forwards and backs analysed separately, GOT, GPT, LDH, and CK levels increased significantly during the camp (all $\mathrm{p}<0.01$ ). The magnitude of change in LDH level was significantly greater in the forwards than in the backs $(\mathrm{p}<0.05)$. Although not statistically significant, the extent of change in the other parameters was also greater in forwards than in backs.

Table 5 shows the changes in WBC, immunoglobulin, and complement levels during the camp. In all players, IgG and IgM levels decreased significantly after the camp $(\mathrm{p}<0.05$ and $\mathrm{p}<0.01$, respectively), while $\mathrm{C} 4$ level increased $(\mathrm{p}<0.01)$. C4 levels increased significantly only in the backs.

The changes in $\mathrm{Hb}, \mathrm{Hct}, \mathrm{Fe}$, and electrolytes during the camp are shown in table 6. No statistically significant differences in $\mathrm{Hb}$ and Hct were observed during the camp. In all players, $\mathrm{Pi}$ and $\mathrm{Na}$ decreased significantly after the camp $(\mathrm{p}<0.05$ in each), while levels of $\mathrm{K}$ increased significantly $(p<0.01)$. Changes were significant in both forwards and backs for $\mathrm{Pi}(\mathrm{p}<0.05$ and $\mathrm{p}<0.01$, respectively) and $\mathrm{K} \quad(\mathrm{p}<0.01$ for each group $)$. In contrast, $\mathrm{Na}$ level decreased significantly in the backs only $(\mathrm{p}<0.01)$.

\section{DISCUSSION}

This study has two limitations. The first limitation is that water ingestion was not measured during camp. However, there was no change in haematocrit values between the two time points (before and after camp) as mentioned below, so we think that dehydration had very little influence on blood parameters. The second limitation is that we have not shown any detailed data regarding the intensity of exercise in this camp. The third limitation is that we did not perform a dietary survey during the camp.

Previous studies examining responses to exercise under hot conditions in other Japanese sportspersons, including baseball players, ${ }^{4}$ managers, ${ }^{5}$ and judges, ${ }^{6}$ have reported a high sweat rate and reduced body weight after a $2 \mathrm{~h}$ exposure to a hot environment. In the present study, we did not measure changes in body weight before and after exercise each day, although the blood biochemical data suggested a high sweat rate in the subjects. Because body weight did not change significantly after the training camp, however, we presume that water ingestion during or after daily exercise compensated for the loss of water due to sweating.

$\mathrm{Hb}$ and Hct levels are used to assess hydration status and increases in blood concentration of various substances resulting from high sweat rates after exercise. Physical activity in a hot environment accelerates sweat loss and

Table 2 Changes in serum total protein, albumin, and lipids during the camp

\begin{tabular}{|c|c|c|c|c|c|c|}
\hline \multirow[b]{2}{*}{ Variable } & \multicolumn{2}{|c|}{ All players $(n=25)$} & \multicolumn{2}{|c|}{ Forward players $(n=12)$} & \multicolumn{2}{|c|}{ Back players $(n=13)$} \\
\hline & Before & After & Before & After & Before & After \\
\hline $\begin{array}{l}\text { Total protein }(\mathrm{g} / \mathrm{dl}) \\
\text { Albumin }(\mathrm{g} / \mathrm{dl}) \\
\text { Total cholesterol }(\mathrm{mg} / \mathrm{dl}) \\
\text { HDL-cholesterol }(\mathrm{mg} / \mathrm{dl}) \\
\text { Triglyceride }(\mathrm{mg} / \mathrm{dl})\end{array}$ & $\begin{array}{c}7.1 \pm 0.5 \\
4.6 \pm 0.2 \\
177.1 \pm 25.3 \\
55.6 \pm 8.0 \\
150.8 \pm 143.6\end{array}$ & $\begin{array}{c}6.9 \pm 0.4 \\
4.7 \pm 0.2 \\
155.2 \pm 16.7^{* *} \\
58.2 \pm 7.5 \\
72.0 \pm 20.1^{* *}\end{array}$ & $\begin{array}{c}7.2 \pm 0.5 \\
4.7 \pm 0.2 \\
170.9 \pm 20.0 \\
55.6 \pm 7.5 \\
115.3 \pm 107.4\end{array}$ & $\begin{array}{c}7.0 \pm 0.4 \\
4.6 \pm 0.2 \\
152.6 \pm 16.0^{*} \\
56.9 \pm 7.2 \\
96.2 \pm 26.5\end{array}$ & $\begin{array}{c}7.1 \pm 0.5 \\
4.5 \pm 0.2 \\
183.6 \pm 29.5 \\
55.5 \vee 8.9 \\
189.3 \pm 171.2\end{array}$ & $\begin{array}{c}6.9 \vee 0.3 \\
4.7 \pm 0.2^{*} \dagger \\
157.0 \pm 17.4^{* *} \\
59.1 \pm 7.9 \\
71.1 \pm 16.6^{*}\end{array}$ \\
\hline
\end{tabular}

Values are the mean $\pm S D$. Before, before the camp; After, After the camp.

${ }^{*} p<0.05,{ }^{* *} p<0.01$, significant difference from the value before the camp; $\uparrow p<0.05$, significant difference between the change in level of forward players during the camp and those of back players. 
Table 3 Changes in serum uric nitrogen, creatinine, and uric acid during the camp

\begin{tabular}{|c|c|c|c|c|c|c|}
\hline \multirow[b]{2}{*}{ Variable } & \multicolumn{2}{|c|}{ All players $(n=25)$} & \multicolumn{2}{|c|}{ Forward players ( $n=12)$} & \multicolumn{2}{|c|}{ Back players $(n=13)$} \\
\hline & Before & After & Before & After & Before & After \\
\hline $\begin{array}{l}\text { Uric nitrogen }(\mathrm{mg} / \mathrm{dl}) \\
\text { Creatinine }(\mathrm{mg} / \mathrm{dl}) \\
\text { Uric acid }(\mathrm{mg} / \mathrm{dl})\end{array}$ & $\begin{array}{r}14.6 \pm 4.2 \\
1.0 \pm 0.2 \\
6.5 \pm 1.6\end{array}$ & $\begin{array}{c}17.0 \pm 2.9^{* *} \\
1.0 \pm 0.1 \\
5.6 \pm 1.1^{* *}\end{array}$ & $\begin{array}{r}13.9 \pm 3.2 \\
1.0 \pm 0.2 \\
6.9 \pm 0.7\end{array}$ & $\begin{array}{c}17.0 \pm 2.5^{\star *} \\
1.0 \pm 0.1 \\
6.2 \pm 1.0^{* *}\end{array}$ & $\begin{array}{r}15.3 \pm 5.0 \\
1.0 \pm 0.2 \\
6.2 \pm 2.1\end{array}$ & $\begin{array}{c}17.0 \pm 3.2^{*} \\
1.0 \pm 0.1 \\
5.2 \pm 1.0\end{array}$ \\
\hline
\end{tabular}

Values are the mean $\pm S D$. Before, before the camp; After, after the camp.

${ }^{*} p<0.05,{ }^{* *} p<0.01$, significant difference from the value before the camp.

consequent dehydration, resulting in increases in blood $\mathrm{Hb}$ and Hct levels. ${ }^{7}$ Although the summer training camp in the present study took place in a hot environment, $\mathrm{Hb}$ and Hct levels did not change significantly after the camp. We speculate that the athletes ingested sufficient water during and after daily exercise to compensate for water lost through sweating.

The significant decrease in TG and TC observed after the camp in the present study was consistent with previous studies showing that aerobic exercise promotes lipid metabolism and consequently reduces lipid levels in the serum. ${ }^{8}$ We observed a significant rise in serum BUN level after the camp. Previous studies reported no change in serum BUN level after brief, intense exercise, ${ }^{9}$ but an increase immediately and $6 \mathrm{~h}$ after prolonged exercise. ${ }^{10}$ Our results suggest that exercise during the camp may have caused skeletal muscle trauma, protein catabolism, and degradation of body tissue proteins in excess of the ability of the kidney to excrete these byproducts.

Serum UA levels increase even after brief exercise, and remain high for several days after endurance exercise such as a marathon race. ${ }^{11}{ }^{12}$ This suggests that exercise may induce renal dysfunction by decreasing renal blood flow during vigorous exercise. ${ }^{11}{ }^{12}$ In the present study, serum UA declined significantly after the camp, despite indications of muscle injury and degradation of somatic tissue proteins, such as increased levels of $\mathrm{K}, \mathrm{BUN}$, and $\mathrm{CK}$. It is possible that the increased water intake caused an increase in UA excretion in the subjects due to increased urination. ${ }^{13}$

Myogenic enzymes such as GOT, GPT, CK, and LDH leak into the blood from myocytes injured during exercise. ${ }^{14} 15$ Physical exercise liberates these enzymes by inducing muscular inflammation and collapse of skeletal muscle, or by increasing the permeability of the muscle cell membrane. ${ }^{16}{ }^{17}$ These enzymes provide a useful marker of skeletal muscle damage and severity of muscular fatigue induced by exercise. $^{1517}$ Of these enzymes, CK increases more in untrained subjects than in habitual exercisers during exercise of similar intensity. ${ }^{18}$ The athletes in the present study had trained regularly before the study began, and their muscles should thus have had some protection against muscle damage. And yet levels of GOT, GPT, LDH, and CK increased significantly after the camp. This suggests a possible accumulation of fatigue due to daily intense exercise, which may induce muscle injury and degradation of somatic tissue proteins throughout the camp period.

There are conflicting reports regarding changes in immunoglobulin levels after exercise; immunoglobulin levels may increase, ${ }^{1920}$ decrease, ${ }^{21}$ or remain unchanged. ${ }^{22}{ }^{23}$ In the present study, serum IgG and IgM levels decreased and C4 levels increased after the summer training camp. The reason for these changes is unknown, but the intensity of exercise may influence the levels of these immune markers.

A significant decrease in $\mathrm{Pi}$ and Na levels $(\mathrm{p}<0.01)$ and a significant rise in $\mathrm{K}$ level $(\mathrm{p}<0.01)$ for all players were observed with regard to electrolytes after the camp. Furthermore, Na level decreased significantly in the backs only $(\mathrm{p}<0.01)$. Na in perspiration and urine and $\mathrm{Pi}$ in urine are reported to increase for a given workload, in proportion to the intensity of exercise. ${ }^{24}$ Therefore, the post-camp decrease in Na and Pi levels as observed in the present study was thought to be due to the excretion of large amounts of $\mathrm{Na}$ and $\mathrm{Pi}$ into the urine as a result of the repeated long daily periods of exercise. ${ }^{2425}$ On the other hand, K increased significantly after the camp. $\mathrm{K}$ is released from skeletal muscle due to acidosis caused by exercise. Furthermore, the contact play specific to rugby football injured the active muscle of players, which led to the increase of $\mathrm{K}$ levels in this study.

We also examined if the players' positions (that is, forwards or backs) induced different blood biochemistry levels. $\mathrm{Hb}$ and Hct levels are indices of dehydration. After the camp, these variables decreased non-significantly in forward players, whereas $\mathrm{Hb}$ and $\mathrm{Hct}$ increased in the backs, suggesting dehydration in the latter group. After the training camp, a significant increase in Alb and decrease in TG occurred only in back players. Furthermore, Na levels decreased significantly in the backs only $(p<0.01)$. It is possible that differences in the blood chemistry profile reflect differences in training demands between back and forward players. For example, training for backs involves more running than for forwards, resulting in a high consumption of TG. In addition, the higher volume of running performed by the backs caused a higher sweat rate during exercise, concentrating the blood and causing a significant increase in their Alb levels. The increase in serum Alb levels seen in the

Table 4 Changes in serum GOT, GPT, LDH, and LDH during the summer training camp

\begin{tabular}{|c|c|c|c|c|c|c|}
\hline \multirow[b]{2}{*}{ Variable } & \multicolumn{2}{|c|}{ All players $(n=25)$} & \multicolumn{2}{|c|}{ Forward players $(n=12)$} & \multicolumn{2}{|c|}{ Back players $(n=13)$} \\
\hline & Before & After & Before & After & Before & After \\
\hline $\begin{array}{l}\text { GOT (U/I) } \\
\text { GPT (U/I) } \\
\text { LDH (U/I) } \\
\text { CK (U/I) }\end{array}$ & $\begin{array}{r}22.0 \pm 10.9 \\
12.4 \pm 11.5 \\
193.4 \pm 38.2 \\
248.0 \pm 280\end{array}$ & $\begin{array}{c}46.5 \pm 22.0^{*} \\
23.3 \pm 13.6^{*} \\
365.4 \pm 102.1^{*} \\
1540.0 \pm 1051^{*}\end{array}$ & $\begin{array}{r}25.7 \pm 14.0 \\
16.9 \pm 14.3 \\
197.9 \pm 38.9 \\
288.0 \pm 379\end{array}$ & $\begin{array}{c}56.4 \pm 27.9^{*} \\
30.1 \pm 18.6^{*} \\
428.0 \pm 111.9^{*} \\
1814.0 \pm 1187^{*}\end{array}$ & $\begin{array}{c}18.0 \pm 3.4 \\
7.5 \pm 4.1 \\
188.5 \pm 38.6 \\
205.0 \pm 996\end{array}$ & $\begin{array}{c}39.5 \pm 13.6^{*} \\
18.4 \pm 5.1^{*} \\
320.7 \pm 68.0^{*} \dagger \\
1345.0 \pm 984^{*}\end{array}$ \\
\hline
\end{tabular}

Values are the mean $\pm S D$. Before, before the camp; After, after the camp.

${ }^{*} p<0.01$, significant difference from the value before the camp; $+p<0.05$, significant difference between the change in level of forward players during the camp and those of back players. 
Table 5 Changes in white blood cell count, serum immunoglobulins, and complements during the camp

\begin{tabular}{|c|c|c|c|c|c|c|}
\hline \multirow[b]{2}{*}{ Variable } & \multicolumn{2}{|c|}{ All players $(n=25)$} & \multicolumn{2}{|c|}{ Forward players $(n=12)$} & \multicolumn{2}{|c|}{ Back players $(n=13)$} \\
\hline & Before & After & Before & After & Before & After \\
\hline $\begin{array}{l}\text { WBC (cells/mm }{ }^{3} \text { ) } \\
\lg G(\mathrm{mg} / \mathrm{dl}) \\
\lg A(\mathrm{mg} / \mathrm{dl}) \\
\lg M(\mathrm{mg} / \mathrm{dl}) \\
\text { C3 (mg/dl) } \\
\text { C4 (mg/dl) }\end{array}$ & $\begin{array}{c}6550.0 \pm 1385 \\
1183.0 \pm 259 \\
190.0 \pm 63.6 \\
124.4 \pm 48.8 \\
100.8 \pm 16.8 \\
21.8 \pm 4.8\end{array}$ & $\begin{array}{c}6220.0 \pm 1128 \\
1090.0 \pm 220^{*} \\
177.8 \pm 51.3 \\
106.1 \pm 43.4^{* *} \\
101.8 \pm 10.7 \\
26.7 \pm 5.4^{* *}\end{array}$ & $\begin{array}{c}6569.0 \pm 1520 \\
1286.0 \pm 299 \\
194.9 \pm 68.2 \\
129.1 \pm 39.9 \\
105.1 \pm 20.7 \\
22.0 \pm 6.0\end{array}$ & $\begin{array}{c}6260.0 \pm 862 \\
1154.0 \pm 263 \\
163.5 \pm 45.4 \\
103.4 \pm 33.5^{*} \\
102.0 \pm 11.8 \\
25.4 \pm 6.2\end{array}$ & $\begin{array}{c}6531.0 \pm 1298 \\
1070.0 \pm 168 \\
184.8 \pm 60.8 \\
119.3 \pm 58.3 \\
96.1 \pm 10.0 \\
21.7 \pm 3.2\end{array}$ & $\begin{array}{c}6192.0 \pm 1317 \\
1045.0 \pm 179 \\
188.1 \pm 54.4 \\
108.1 \pm 50.5^{* *} \\
101.6 \pm 10.2 \\
27.6 \pm 4.8^{* *}\end{array}$ \\
\hline
\end{tabular}

Values are the mean $\pm S D$. Before, before the camp; After, after the camp; WBC, white blood cell count.

${ }^{*} p<0.05,{ }^{* *} p<0.01$, significant difference from the value before the camp.

Table 6 Changes in haemoglobin, haematocrit, iron, and electrolytes during the camp

\begin{tabular}{|c|c|c|c|c|c|c|}
\hline \multirow[b]{2}{*}{ Variable } & \multicolumn{2}{|c|}{ All players $(n=25)$} & \multicolumn{2}{|c|}{ Forward players $(n=12)$} & \multicolumn{2}{|c|}{ Back players $(n=13)$} \\
\hline & Before & After & Before & After & Before & After \\
\hline Haemoglobin (g/dl) & $14.6 \pm 1.2$ & $14.6 \pm 16.6$ & $14.6 \pm 1.3$ & $14.4 \pm 1.2$ & $14.5 \pm 1.1$ & $14.8 \pm 1.9$ \\
\hline Haematocrit (\%) & $47.4 \pm 3.3$ & $46.6 \pm 4.5$ & $47.7 \pm 3.5$ & $45.6 \pm 2.9$ & $47.0 \pm 3.3$ & $47.2 \pm 5.4$ \\
\hline $\mathrm{Fe}(\mu \mathrm{g} / \mathrm{dl})$ & $83.0 \pm 28.7$ & $95.5 \pm 27.6$ & $87.5 \pm 96.2$ & $96.2 \pm 26.5$ & $78.2 \pm 39.5$ & $95.0 \pm 29.3$ \\
\hline $\mathrm{Ca}(\mathrm{mg} / \mathrm{dl})$ & $9.2 \pm 0.2$ & $9.0 \pm 0.4$ & $9.2 \pm 0.2$ & $8.9 \pm 0.3$ & $9.3 \pm 0.2$ & $9.1 \pm 0.4$ \\
\hline $\mathrm{Pi}(\mathrm{mg} / \mathrm{dl})$ & $4.5 \pm 0.5$ & $3.9 \pm 0.4^{* *}$ & $4.5 \pm 0.4$ & $4.0 \pm 3.1^{*}$ & $4.4 \pm 0.5$ & $3.9 \pm 0.4^{* *}$ \\
\hline $\mathrm{Na}(\mathrm{mEq} / \mathrm{l})$ & $142.8 \pm 1.2$ & $140.8 \pm 1.9^{* *}$ & $142.9 \pm 1.4$ & $141.2 \pm 1.4$ & $142.7 \pm 0.5$ & $140.5 \pm 2.2^{* *}$ \\
\hline $\mathrm{K}(\mathrm{mEq} / \mathrm{l})$ & $4.1 \pm 0.3$ & $4.7 \pm 0.3^{* *}$ & $4.2 \pm 0.3$ & $4.8 \pm 0.4^{\star \star}$ & $4.0 \pm 0.2$ & $4.7 \pm 0.3^{* *}$ \\
\hline $\mathrm{Cl}(\mathrm{mEq} / \mathrm{l})$ & $103.6 \pm 1.6$ & $104.4 \pm 2.1$ & $103.4 \pm 1.5$ & $104.5 \pm 2.7$ & $103.8 \pm 1.8$ & $104.3 \pm 1.7$ \\
\hline
\end{tabular}

Values are the mean $\pm S D$. Before, before the camp; After, after the camp.

${ }^{*} p<0.05,{ }^{* *} p<0.01$, significant different from the value before the camp.

mornings is also indicative of the fact that normal blood concentration was not restored by overnight rest after exercise.

In contrast, serum LDH levels changed more in forwards than in backs. A similar tendency was observed for another serum enzyme, BUN, although this was not significant. These results suggest that muscle injury and accompanying degradation of somatic tissue proteins occurred more in forwards than in backs, which may be a reflection of the training demands imposed on forwards involving the inclusion of more muscular strength-oriented exercises such as scrum play (in which two groups of opposing players push against each other) and direct physical contact with other players. These data suggest that blood biochemistry may differ between rugby players playing in different positions, even if they are playing in the same game.

In conclusion, these data suggest that a 20 day intensive summer training camp induced muscle injury, loss of electrolytes through sweating, and changes in immune function in university rugby football players. Comparison between forwards and backs suggests that responses differ according to the player's position. Backs, who ran more during the camp, exhibited changes in lipid metabolism, loss of electrolytes, and dehydration. In contrast, forwards, who are stronger and experience more physical contact, exhibited indicators of muscle injury and degradation in somatic tissue proteins. Accordingly, managers and coaches should develop position-specific exercise patterns and subsequent care and resting programs for rugby players during and after summer camps, which the players themselves should be encouraged to follow carefully.

\section{ACKNOWLEDGEMENTS}

The authors are grateful to students of Waseda University rugby football team for their participation in this survey.

\section{Authors' affiliations}

T Mashiko, Department of Health and Physical Education, National Defense Medical College, Namiki 3-2, Tokorozawa, Saitama 359-8513, Japan
T Mashiko, T Umeda, S Nakaji, K Sugawara, Department of Hygiene, Hirosaki University School of Medicine, Zaifu-cho 5, Hirosaki City, 036-8562 Aomori, Japan

Conflict of interest: none declared.

\section{REFERENCES}

1 The Japan Rugby Football Association. Manual for safety measures in rugby football. Tokyo: Yamato Press, 1993:2-3 (in Japanese).

2 Sawada $Y$, Wataai K, Sakai $H$, et al. Rugby injury during summer camp at Sugadaira' '88. Jpn J Orthop Sports Med 1990;9:123-5 (in Japanese).

3 Mihara H, Hachya M, Ohnari K, et al. Study of trauma during the training summer camp in a college rugby-football team. Jpn J Orthop Sports Med 1995; 15:391-8 (in Japanese).

4 Kurakake S, Nakaji S, Sugawara K, et al. A study on the effects of physical load on high school baseball players during midsummer games. Nippon Eiseigaku Zasshi 1995;50(2):604-15 (in Japanese).

5 Umeda T, Nakaji S, Sugawara K, et al. A study on the effects of physical load placed on high school baseball managers during midsummer games. Nippon Eiseigaku Zasshi 1998;52(4):641-6 (in Japanese).

6 Kurakake S, Nakaji S, Sugawara K, et al. A study of the effects of physical load on umpires during the national high school baseball games - the effects of physical load on umpires at the Koshien stadium in a summer-heat environment. Nippon Eiseigaku Zasshi 1998;52(4):667-76 (in Japanese).

7 Harrison MH. Effects of thermal stress and exercise on blood volume in humans. Physiol Rev 1985;65(1): 149-209.

8 Durstine JL, Grandjean PW, Davis PG, et al. Blood lipid and lipoprotein adaptations to exercise: a quantitative analysis. Sports Med $2001 ; 31(15): 1033-62$.

9 Lamont LS, Lemon PW, Bruot BC. Menstrual cycle and exercise effects on protein catabolism. Med Sci Sports Exerc 1987;19(2):106-10.

10 Plante RI, Houston ME. Exercise and protein catabolism in women. Ann Nutr Metab 1984;28(2): 123-9

11 Klapcinska B, Iskra J, Poprzecki S, et al. The effects of sprint $(300 \mathrm{~m})$ running on plasma lactate, uric acid, creatine kinase and lactate dehydrogenase in competitive hurdlers and untrained men. J Sports Med Phys Fitness 2001;41(3):306-11.

12 Janssen GM, Degenaar CP, Menheere PP, et al. Plasma urea, creatinine, uric acid, albumin, and total protein concentrations before and after 15-, 25-, and 42-km contests. Int J Sports Med 1989;10(suppl 3):S132-8.

13 Suzuki M. Sportsman and serum uric acid. J Clin Sport Med 1985;5:573-6 (in Japanese).

14 Apple FS, Rhodes M. Enzymatic estimation of skeletal muscle damage by analysis of changes in serum creatine kinase. J Appl Physiol 1988:65:2598-600

15 Koutedakis Y, Raafat A, Sharp NC, et al. Serum enzyme activities in individuals with different levels of physical fitness. J Sports Med Phys Fitness 1993;33:252-7.

16 Flynn MG, Pizza FX, Boone JB Jr, et al. Indices of training stress during competitive running and swimming seasons. Int J Sports Med 1994;15:21-6. 
17 Olerud JE, Homer LD, Carroll HW Incidence of acute exertional rhabdomyolysis. Serum myoglobin and enzyme levels as indicators of muscle injury. Arch Intern Med 1976;136:692-7.

18 Evans WJ, Meredith CN, Cannon JG, et al. Metabolic changes following eccentric exercise in trained and untrained men. J Appl Physiol 1986;61:1864-8.

19 Nieman DC, Hehlsen-Cannarella SL. The effects acute and chronic exercise of immunoglobulins. Sports Med 1991;11:183-201.

20 Nehlsen-Cannarella SL, Nieman DC, Balk-Lamberton AJ, et al. The effects of moderate exercise training on immune response. Med Sci Sports Exerc $1991 ; 23(1): 64-70$.
21 Mackinnon LT, Hooper S. Mucosal (secretory) immune system responses to exercise of varying intensity and during overtraining. Int I Sports Med 1994; 15(suppl 3):S179-83.

22 Poortmans JR. Serum protein determination during short exhaustive physical activity. J Appl Physiol 1971;30(2):190-2.

23 Nieman DC, Tan SA, Lee W, et al. Complement and immunoglobulin levels in athlete and sedentary controls. Int J Sports Med 1989;10:124-8.

24 Nose H, Takamata R. Humor modulation under exercise. J Clin Sport Med 1997:14:712-7 (in Japanese)

25 Suzuki $M$. Change in renal function by exercise. Med Technol 1996;24:989-2 (in Japanese). 